\title{
The classification of Russian soils on the basis of transfer factors of radionuclides from soil to farm crops
}

\author{
N.I. Sanzharova, S.V. Fesenko and S. Spiridonov \\ Russian institute of Agricultural Radiology and Agroecology, Kievskoye shosse $109 \mathrm{~km}$, \\ 249020 Obninsk, Kaluga Region, Russia
}

\begin{abstract}
The accumulation of radionuclides in crops varies considerably for different soil-climatic zones being. largely dependent on the soil properties. To group the data, relationships between TFs to different crops and soil properties were analysed. As a criterion for classification of mineral soils by transfer factors the granulometric composition (texture) was chosen. The generalisation of data within the identified soil groups has demonstrated that for different crop/soil combinations the volume of sampling is not the same. Therefore, a statistical processing of data was carried out. Clear-cut relationships between ${ }^{90} \mathrm{Sr}$ and ${ }^{137} \mathrm{Cs}$ accumulation in different crops and identified soil groups were found. The obtained data allowed us to derive rather stable ratios of geometric means for transfer factors for different soil groups which confirm the validity of data generalisation within the identified soil groups.
\end{abstract}

\section{INTORDUCTION}

The performed studies on the regularities of radionuclide migration within the soil-plant system have enabled the obtaining of data which can be the basis for the classification of soils by radioecological criteria. Such a classification makes it possible to predict the contamination of agricultural stuffs and to determine the intervention levels in the event of radioactive contamination of the agricultural land.

The integral indicators reflecting the peculiar features of the radionuclide behavior in soils of different types is the transfer factors. Transfer factors depend on characteristics of radioactive fallout, plant species, soil properties, time after contamination. After the Chernobyl accident special data base for transfer factors from different soil types to plants was developed. These data was used for evaluation of radionuclide behavior in agricultural systems and for radioecological classification of soils.

\section{DESCRIPTION OF SOILS FOR THE CONTAMINATED REGIONS OF RUSSIA}

Within Russia, there are more than $\mathbf{3 0 0}$ soil types and sub-types. The soil classification system in Russia is rather complex. The whole territory is divided into soil-geographic regions homogeneous in soil cover. The Chemobyl accident resulted in the contamination of soils with widely varying soil characteristics. The main soil types in the contaminated zone are soddy-podzolic, soddy-gleyed and soddy soils of different mechanical composition; grey forest soils and chemozems of different subtypes; peaty soils etc. According to FAO/UNESCO Soil Classification System there are six soil groups in the most contaminated areas of Russia - Podzoluvisols, Gleysols, Histosols, Fluvisols, Greyzems, Chernozems.

Table 1. Comparison of Russian and FAO/UNESCO Soil Classification Systems

\begin{tabular}{|c|c|c|c|}
\hline $\begin{array}{l}\text { Type of soil according to Rus- } \\
\text { sian Classification }\end{array}$ & $\begin{array}{l}\text { Type of soil according to } \\
\text { FAOI UNESCO Classifi- } \\
\text { cation }\end{array}$ & $\begin{array}{l}\text { Type of soil according to Rus- } \\
\text { sian Classification }\end{array}$ & $\begin{array}{l}\text { Type of soil according to } \\
\text { FAOANESCO Classifi- } \\
\text { cation }\end{array}$ \\
\hline $\begin{array}{l}\text { Podzolic } \\
\text { Soddy-podzolic } \\
\text { Soddy-podzolic gley(ed) } \\
\text { Gley } \\
\text { Soddy-gley } \\
\text { Peaty-gley, Alluvial soddy-gley } \\
\text { Boggy } \\
\text { Peaty, Peaty- swamp } \\
\text { Humic-peaty }\end{array}$ & $\begin{array}{l}\text { Podzoluvisols } \\
\text { Eutric Podzoluvisols } \\
\text { Gleyic Podzoluvisols } \\
\text { Gleysols } \\
\text { Eutric Gleysols } \\
\text { Dystric Gleysols } \\
\text { Histosols } \\
\text { Eutric Histosols } \\
\text { Dystric Histosols }\end{array}$ & $\begin{array}{l}\text { Alluvial } \\
\text { Alluvial-flood plain } \\
\text { Soddy, Alluvial Soddy } \\
\text { Grey forest } \\
\text { Light grey forest and grey forest } \\
\text { Dark grey forest } \\
\text { Grey forest gley (ed) } \\
\text { Chernozems } \\
\text { Chernozem podzolized } \\
\text { Chernozem leached } \\
\text { Meadow-chemozem }\end{array}$ & $\begin{array}{l}\text { Fluvisols } \\
\text { Dystric Fluvisols } \\
\text { Eutric Fluvisots } \\
\text { Greyzems } \\
\text { Orthic Greyzems } \\
\text { Mollic Greyzems } \\
\text { Gleyic Greyzems } \\
\text { Chernozens } \\
\text { Luvic Chemozems } \\
\text { Luvic Chemozems } \\
\text { Haptic Chemozem }\end{array}$ \\
\hline
\end{tabular}




\subsection{Soil characteristics of the experimental plots}

To derive quantitative parameters of radionuclide migration from different soils to farm crops, experimental studies have been performed in different soil-climatic zones of Russia in 1999-2000. The experimental plots were chosen in the Rostov, Voronezsh, Kursk, Orel, Tula and Bryansk regions. In the Rostov region the soil cover is dominated by chestnut soils (Haplic Kastanozems). In the Voronezsh region, experimental plots are located on different sub-types of chernozem (typical and ordinary chemozems Chemic Chernozem and Harlic Chernozem). In the Kursk region podzolized, leached and typical chernozems are presented (Grey-Luvic Chernozem, Luvic Chernozem and Chernic Chernozem). The experimental plots in the Orel and Tula regions are located on leached chemozem (Luvic Chemozem) and grey forest soil (Albic Luvisols). In the Bryansk region soddy-podzolic sandy loam and light loam soils (Umbric Podzols), meadow-swamp soil (Histic Gleysols), peat soil (Eutri-Histic Gleysols) are presented..

Soil of the experimental plots differ significantly in their properties. Intervals of data are following: $\mathrm{pH}_{\mathrm{KCl}} 4.6-7.4 ; \mathrm{pH}_{\mathrm{H} 2 \mathrm{O}} 4.91-7.59 ; \mathrm{OM} \mathrm{0.56-3.21 \%}$ for mineral soils and 25.2 for peat; $\mathrm{K}_{\text {exch }} 0.13-2.07$ cmol $\mathrm{kg}^{-1}$; $\mathrm{Ca}_{\text {exch }} 4.1-32.4 \mathrm{cmol}_{\mathrm{c}} \mathrm{kg}^{-1}$ for mineral soils and 52 for peat; CEC $8.3-45.9 \mathrm{cmol}_{\mathrm{c}} \mathrm{kg}^{-1}$ for mineral soils and 68,5 for peat. Soddy-podsolic and Grey forest soils show a low content of humus and cation exchange capacity, acid reaction of soil solution. Chernozem soil shows a higher content of the organic matter and cation exchange capacity. A granulometric analysis of soils was performed by N.A. Kachinsky's method [1]. It shows that the soils studied are highly variable in content of particles of different size. Thus, the content of physical clay (content of particles $<0,01 \mathrm{~mm}$ ) varies from 8.33 to $61.86 \%$.

\section{RESULTS AND DISCUSSION}

\subsection{Accumulation of radionuclides by crops from different soils}

The accumulation of radionuclides in farm crops varies considerably for different soil-climatic zones being largely dependent on the soil properties. Among the key factors influencing $\mathrm{TFs}^{90} \mathrm{Sr}^{137} \mathrm{Cs}$, soil properties and biological peculiarities of crops need to be pointed out. The differences in TFs ${ }^{137} \mathrm{Cs}$ for different soil types reach 40 times. The differences in the accumulation of radionuclides by different crops species vary from 2 to 10 times. The highest availability of the radionuclide is reported for peat, meadowswamp (Histic Gleysols) and soddy-podzolic sandy and sandy loam soils (Umbric Podzols). Soils with higher fertility and heavier mechanical composition retain radionuclide more strongly.

The differences in TFs ${ }^{90} \mathrm{Sr}$ for different soil types reach 6,4 times for barley and cabbage and 19 times for potato. The differences in the accumulation of radionuclides by different crops species vary from 3 to 13 times. The highest availability of the radionuclide is reported for soddy-podzolic sandy and grey forest soils.

The studies have shown that radionuclides from chemozem soils are less accumulated by plants than those from grey forest (Grey-Luvic Phaeozem), soddy-podzolic (Umbric Podzols) and peat soils (Eutri-Histic gleysols).

The behaviour of ${ }^{137} \mathrm{Cs}$ and ${ }^{90} \mathrm{Sr}$ is different. ${ }^{137} \mathrm{Cs}$ exist in soil mainly in the nonexchangeable form, whereas ${ }^{90} \mathrm{Sr}$, on the contrary, is characterized by an exchangeable type of sorption in soils. The accumulation of ${ }^{90} \mathrm{Sr}$ by all crops is higher than of ${ }^{137} \mathrm{Cs}$. The differences amount from 1.9 to 15.2 times for cereals, 1.2-10.2 times for potato and 3.9-75 times for cabbage. An exclusion is the accumulation of radionuclides by potato from peat soil, $\mathrm{TF}^{90} \mathrm{Sr}$ is by a factor of 3 less than $\mathrm{TF}^{137} \mathrm{Cs}$.

\subsection{Influence of soil properties on uptake of ${ }^{137} \mathrm{Cs}$ and ${ }^{90} \mathrm{Sr}$ by the crops}

Distinctions in ${ }^{137} \mathrm{Cs}$ and ${ }^{90} \mathrm{Sr}$ accumulation from different soil types result from the influence of soil characteristics which are responsible for the biological availability of radionuclides. A preliminary data analysis shown that ${ }^{137} \mathrm{Cs}$ accumulation is inversely proportional to the contents of exchangeable potas- 
sium and calcium, cation exchange capacity, content of particles $<0.01 \mathrm{~mm}$ (physical clay). These regularities, however, reveal themselves in varying degrees among different crops - clear-cut relationships have been found for cereals but for potato and cabbage the observed regularities are not so weil pronounced.

A trend towards declining in $\mathrm{TFs}{ }^{137} \mathrm{Cs}$ to cereal crops and potato is noted with the declining soil acidity. A reverse relationship is however, observed for cabbage. It should be noted that the estimation of the acidity effects must take into account the relation of different crops to the medium reaction. Thus, cabbage belongs to crops which grow well only with neutral or weak alkaline reaction (pH 7-8); barley, spring and winter rye grow well only with neutral or weak acidic reaction $(\mathrm{pH}$ 6-7); potato is insensitive to acidic reaction and grows well on acid soils; rye grows reasonably well in a wide range of pH, but the most favourable for development is a weak acidic reaction (pH 5,5-6).

The infuuence of organic matter is also different - for cereal crops a decrease in ${ }^{137} \mathrm{Cs}$ accumulation by plants is observed with the increase in the organic matter content in soil; for potato and cabbage this relationship is less pronounced. Mention should be made that the difficulty of identification of certain relations for cabbage and potato is largely caused by differences in their cultivation technologies, since some samples were taken in the private kitchen-garden.

All the crops show a dependence of the accumulation coefficients on the content of physical clay $(<0.01 \mathrm{~mm}$ ), i.e. on soil granulometric composition (texture). Granulometric composition is integral indicator, which connect with soil mineral composition, content of cations, cation exchange capacity, etc.

For ${ }^{90} \mathrm{Sr}$, the dependence of the TFs on various soil properties differs from that of ${ }^{137} \mathrm{Cs}$. Poorly expressed is the relation between ${ }^{90} \mathrm{Sr}$ accumulation in crops and soil content of exchangeable potassium. At the same time, ${ }^{90} \mathrm{Sr}$ TFs tend to decrease for all the crops studied with the increase in soil of exchangeable calcium and cation exchange capacity. The effect of soil acidity on $\mathrm{TF}{ }^{90} \mathrm{Sr}$ is insignificant and it is rather difficult to reveal certain regularities. The data obtained suggest that soil organic matter influences the behaviour of ${ }^{90} \mathrm{Sr}$ - with increase in soil of organic matter, the decrease in the radionuclide transfer to plants is observed. Less district is the relationship between $\mathrm{TFs}{ }^{90} \mathrm{Sr}$ and soil granulometric composition (texture).

\subsection{Statistical processing of data}

To identify the most significant soil characteristics (in terms of their influence on ${ }^{137} \mathrm{Cs}$ accumulation rate in plants) and to establish quantitative relation between TFs and soil parameters, data have been statistically processed.

\subsubsection{Correlation analysis}

The first stage of data processing used method of correlation analysis. Analysis of the correlation matrix allows an estimation of the extent to which soil characteristics are interrelated. The large part of soil parameters correlate well (Table 2 ).

Table 2. Coefficients of correlation between soil characteristics

\begin{tabular}{|c|c|c|c|c|c|c|c|c|}
\hline & Exch. K & Exch $\mathrm{Ca}$ & CEC & $\mathrm{pH}_{\mathrm{Ka}}$ & $\mathrm{pH}_{\mathrm{H} 2 \mathrm{O}}$ & $\mathrm{OM}$ & Clay & Silt \\
\hline Exch. $K$ & 1,000 & 0,363 & $\overline{0,325}$ & 0,190 & 0,084 & $-0,072$ & 0,152 & 0,168 \\
\hline Exch $\mathrm{Ca}$ & 0,363 & 1,000 & 0,974 & 0,256 & $-0,094$ & 0,259 & 0,792 & 0,799 \\
\hline $\mathrm{CEC}$ & 0,325 & 0,974 & 1,000 & 0,240 & $-0,088$ & 0,351 & 0,795 & 0,801 \\
\hline $\mathbf{P H}_{\mathbf{K a}}$ & 0,190 & $\mathbf{0 , 2 5 6}$ & 0,240 & 1,000 & 0,396 & $-0,148$ & 0,245 & 0,197 \\
\hline $\mathrm{PH}_{4 \mathrm{LO}}$ & 0,084 & $-0,094$ & $-0,088$ & 0,396 & 1,000 & $-0,188$ & $-0,123$ & $.0,181$ \\
\hline OM & $-0,072$ & 0,259 & 0,351 & $-0,148$ & $-0,188$ & 1,000 & $-0,002$ & 0,041 \\
\hline Clay & 0,152 & 0,792 & 0,795 & 0,245 & $-0,123$ & $-0,002$ & 1,000 & 0,959 \\
\hline Silt & 0,168 & 0,799 & 0,801 & 0,197 & $-0,181$ & 0,041 & 0,959 & 1,000 \\
\hline Confidence intervals & \multicolumn{2}{|c|}{$5 \%$} & \multicolumn{3}{|c|}{$1 \%$} & \multicolumn{3}{|c|}{$0.1 \%$} \\
\hline Significance level & \multicolumn{2}{|c|}{0.250} & \multicolumn{3}{|c|}{0.325} & \multicolumn{3}{|c|}{0.408} \\
\hline
\end{tabular}

Ar exclusion are correlation between the following: $\mathrm{K}_{\text {exch }}$ with $\mathrm{pH}_{\mathrm{KCl}}, \mathrm{pH}_{\mathrm{H} 20}, \mathrm{OM}$, content clay and silt; $\mathrm{Ca}_{\text {exch }}$ with $\mathrm{pH}_{\mathrm{KCl}}, \mathrm{pH}_{\mathrm{H} 2 \mathrm{O}} ; \mathrm{CEC}$ with $\mathrm{pH}_{\mathrm{H}_{2}} ; \mathrm{pH}_{\mathrm{KCl}}$ and $\mathrm{pH}_{\mathrm{H}_{2} \mathrm{O}}$ with $\mathrm{OM}$, content clay and silt; $\mathrm{OM}$ 
with content clay and silt. The highest correlation coefficients are between following parameters: $\mathrm{Ca}_{\text {exch }}$ with CEC, content clay and silt; $\mathrm{CEC}$ ' with content clay and silt.

It is, however, impossible based on correlation matrix analysis to uniquely determine quantitative relation between any of two parameters, because of the effects on this relation of the rest parameters. Correlation between $\mathrm{TF}^{137} \mathrm{Cs}$ to plants and soil properties are pronounced for cabbage between $\mathrm{TF}$ and $\mathrm{K}_{\text {exchs }}$ $\mathrm{pH}_{\mathrm{KCl}}$ and $\mathrm{pH}_{\mathrm{H} 2 \mathrm{O}}$; for potato between $\mathrm{TF}$ and content clay and silt; for cereal grain between $\mathrm{TF}$ and $\mathrm{Ca}_{\text {exch, }}$ $\mathrm{pH}_{\mathrm{KCl}}$, content clay and silt. Correlation for cabbage are distinct from those for the rest crops. This most likely results from a small sample size.

\subsubsection{Regression relationships between $T F^{137} \mathrm{Cs}$ to plants and soil characteristics}

A simplest variant of the relationship is the linear regression model (multiple regression):

$$
T F=a+\sum_{i=1, n} b_{i} X \text {, }
$$

where TF is the transfer factor, $X_{i}$ is the $i$-th soil agrochemical characteristics (Table 3 ).

Table 4 summarizes parameters of the model for different crops. The coefficients of multiple correlation $(\mathrm{R})$ are fairly high for all the cases studied.

Table 3. Coefficients of correlation between $\mathrm{TF}{ }^{137} \mathrm{Cs}$ to crops and soil parameters

\begin{tabular}{|c|c|c|c|c|c|c|c|c|c|}
\hline Crop & $\mathbf{N}$ & Ex. K & $\mathrm{Ex} \cdot \mathrm{Ca}$ & CEC & $\mathrm{pH}_{\mathrm{KCI}}$ & $\mathrm{pH}_{\mathrm{H} 2 \mathrm{O}}$ & $\mathrm{OM}$ & Clay & Silt \\
\hline Grain & 26 & $-0,307$ & $-0,524$ & $-0,512$ & $-0,404$ & $-0,098$ & 0,220 & $-0,647$ & $-0,714$ \\
\hline Straw & 26 & $-0,251$ & $-0,424$ & $-0,429$ & $-0,378$ & $-0,083$ & 0,040 & $-0,229$ & $-0,236$ \\
\hline Potato & 18 & $-0,261$ & $-0,259$ & $-0,248$ & $-0,208$ & $-0,216$ & $-0,160$ & $-0,508$ & $-0,524$ \\
\hline Cabbage & 17 & 0,472 & 0,001 & 0,076 & 0,599 & 0,628 & $-0,005$ & 0,066 & 0,099 \\
\hline \multicolumn{2}{|c|}{ Confidence intervals } & \multicolumn{3}{|c|}{$5 \%$} & \multicolumn{2}{|c|}{$1 \%$} & \multicolumn{3}{|c|}{$0.1 \%$} \\
\hline \multirow[t]{3}{*}{ Significance level } & 26 & & 0.374 & & \multicolumn{2}{|c|}{0.478} & \multicolumn{3}{|c|}{0.588} \\
\hline & 18 & & 0.444 & & \multicolumn{2}{|c|}{0.561} & \multirow{2}{*}{\multicolumn{3}{|c|}{0.679}} \\
\hline & 17 & & 0.456 & & \multicolumn{2}{|c|}{0.575} & \multicolumn{2}{|c|}{0.693} & \\
\hline
\end{tabular}

Table 4. Parameters of regression equations describing relations between $\mathrm{TF}^{137} \mathrm{Cs}$ to crops and soil characteristics

\begin{tabular}{|c|c|c|c|c|c|c|c|c|c|c|}
\hline \multirow[b]{2}{*}{ Crop } & \multirow[b]{2}{*}{$a$} & \multicolumn{8}{|c|}{$B_{i}$} & \multirow[b]{2}{*}{ R } \\
\hline & & Exch. K & Exch. Ca & CEC & $\mathrm{PH}_{\mathrm{KCT}}$ & $\mathrm{pH}_{\mathrm{HZO}}$ & $\overrightarrow{O M}$ & Clay & Silt & \\
\hline Grain & 0,0702 & $-0,00464$ & 0,00047 & $-0,00024$ & $-0,00530$ & $-0,00137$ & 0,00212 & 0,00052 & $-0,00183$ & 0,84 \\
\hline Straw & 0,268 & 0,00826 & 0,00395 & $-0,0100$ & $-0,0403$ & 0,00649 & 0,02514 & 0,00270 & 0,00011 & 0,63 \\
\hline Potato & 0,0592 & $-0,00456$ & $-0,00167$ & 0,00262 & $-0,0191$ & 0,0138 & $-0,00040$ & $-0,00057$ & $-0,00147$ & 0,83 \\
\hline Cabage & $-0,0249$ & 0,00339 & $-0,00057$ & 0,000405 & $-0,00974$ & 0,0141 & $-0,00095$ & $-0,00028$ & 0,000393 & 0,77 \\
\hline
\end{tabular}

The results of the graphical analysis of TF dependencies on soil parameters suggest that in most cases these relationships are of a non-linear character. It is therefore wise to employ a non-linear model: $T F=A \cdot X_{1}^{B_{1}} \cdot X_{2}^{B_{2}} \cdot \ldots X_{n}^{B_{m}}$

By linearizing transformation, the equation assumes the form:

$$
\ln (T F)=\ln A+\sum_{i=1, \pi} B_{i} \ln \left(X_{i}\right)
$$

To find parameters of this model, the multiple regression analysis method has been used. The values for the parameters are listed in Table 5. The coefficient of multiple correlation $(R)$ exceed the value for this parameters for linear regression.

Table 5. Parameters of regression equations describing relations between the Jogarithms of $\mathrm{TF}{ }^{137} \mathrm{Cs}$ to

\begin{tabular}{|c|c|c|c|c|c|c|c|c|c|c|}
\hline \multirow[t]{2}{*}{ Crop } & \multirow{2}{*}{$\ln A$} & \multicolumn{8}{|c|}{$B_{1}$} & \multirow[t]{2}{*}{$\mathbf{R}$} \\
\hline & & Exch. $\bar{K}$ & Exch. Ca & CEC & $\mathrm{pH}_{\mathrm{Ka}}$ & $\mathrm{pH}_{\mathrm{H2O}}$ & $\mathrm{OM}$ & Clay & Silt & \\
\hline Grain & $-1,72$ & $-0,288$ & 1,61 & $-1,24$ & $-1,63$ & $-0,217$ & $-0,442$ & 2,92 & $-3,49$ & 0,9 \\
\hline Straw & 5,22 & $-0,319$ & 1,88 & $-3,03$ & $-3,54$ & 0,237 & 0,420 & 1,35 & $-1,17$ & 0,66 \\
\hline Potato & $-1,72$ & $-0,288$ & 1,61 & $-1,24$ & $-1,63$ & $-0,217$ & $-0,442$ & 2,92 & $-3,49$ & 0,9 \\
\hline Cabbage & $-17,8$ & 1,72 & $-2,15$ & 6,46 & $.28,4$ & 30,7 & $-2,59$ & $-0,496$ & $-1,68$ & 0,79 \\
\hline
\end{tabular}
crops and soil characteristics 


\subsubsection{Factor analysis}

The factor analysis method has been applied to determine relations between the parameters studied. The main aim of this method is to detect general latent factors which explain relations between the observed indicators. At the first step both soil characteristics and TF were included in a set of initial data.

A choice of a number of factors was based on the "scree criterion". To use this criterion, a plot of eigenvalues versus their number was analysed. A coordinate of the point where diminishing of eigenvalued is maximally slowed down defines the number of factors. The results of such an analysis for datasheet including soil parameters and $\mathrm{TF}{ }^{137} \mathrm{Cs}$ to grain make it possible to identify three factors. The same factors for straw were identified.

To identify factors, a method of major components has been applied. Factor rotation was carried out by the Varimax method. Factor loads for two datasheets including soil parameters and TF ${ }^{137} \mathrm{Cs}$ to grain and straw are shown in Table 6 . The analysis of the data presented provides information to describe the identified factors. The maximum factor loads on Factor 1 are from the variables such as content clay, content silt, $\mathrm{CEC}, \mathrm{Ca}_{\text {exch }}$. This factor characterizes (mainly) mineral and granulometric soil composition. Factor 2 is largely related to soil acidity. Factor 3 depends on the amount of organic matter. The maximum factor load for TF to grain falls at Factor 1. The maximum factor load for TF to straw falls at Factor 2.

Table 6. Factor loads for two datasheet including soil parameters and TF ${ }^{137} \mathrm{Cs}$ to grain and straw of cereals

\begin{tabular}{|c|c|c|c|c|c|c|}
\hline \multirow{2}{*}{ Variables } & \multicolumn{3}{|c|}{ Grain } & \multicolumn{3}{|c|}{ Straw } \\
\hline & Factor 1 & Factor 2 & Factor 3 & Factor 1 & Factor 2 & Factor 3 \\
\hline TF & $-0,742$ & $-0,306$ & 0,352 & $-0,259$ & $.0,650$ & $-0,123$ \\
\hline Exch. $\mathbf{K}$ & 0,254 & 0,500 & 0,145 & 0,171 & 0,542 & 0,156 \\
\hline Exch. Ca & 0,874 & 0,186 & 0,349 & 0,863 & 0,317 & 0,294 \\
\hline CEC & 0,866 & 0.173 & 0,414 & 0,855 & 0,308 & 0,362 \\
\hline ptea & 0,224 & 0,752 & $-0,155$ & 0,161 & 0,733 & $-0,276$ \\
\hline $8 \div$ & $-0,234$ & 0,787 & $-0,133$ & $-0,279$ & 0,627 & $-0,304$ \\
\hline $\mathrm{OM}$ & 0,040 & $-0,117$ & 0,921 & 0,050 & $-0,066$ & 0,912 \\
\hline Clay & 0,950 & 0,012 & $-0,058$ & 0,965 & 0,060 & $-0,115$ \\
\hline Silt & 0,972 & $-0,030$ & $-0,042$ & 0,971 & 0,029 & $-0,057$ \\
\hline
\end{tabular}

\subsection{Classification of soils on the base soil terture}

Mineral soils were divided into three groups according to their mechanical composition (texture) using N.A. Kachinsky's classification [1] (Table 7).

The generalisation of data within the identified soil groups has demonstrated that for different crop/soil combinations the volume of sampling is not the same. Therefore, a statistical processing of data was carried out.

Table 7. Main characteristics of soils according to the classification used in the study

\begin{tabular}{|c|c|c|c|c|c|c|}
\hline $\begin{array}{l}\text { Soil } \\
\text { group }\end{array}$ & Texture & Soil types, as classified in Russia & $\mathrm{pH}$ & $\mathrm{OM}, \%$ & $\begin{array}{l}\text { Cation exchange } \\
\text { capacity, cmol } \text { kg }^{-1}\end{array}$ & $\begin{array}{l}\text { Content of partic- } \\
\text { les }<0.01 \mathrm{~mm}, \%\end{array}$ \\
\hline Sandy & $\begin{array}{l}\text { Sandy, } \\
\text { Loamy } \\
\text { sand }\end{array}$ & Soddy-podzolic; Grey forest & $4.8-6.7$ & $0.6-1.7$ & $8.7-16.2$ & $8.33-10.32$ \\
\hline Loam & $\begin{array}{l}\text { Light loam, } \\
\text { medium } \\
\text { loam }\end{array}$ & $\begin{array}{l}\text { Soddy-podzolic; Grey and dark } \\
\text { grey forest; Leached chernozem; } \\
\text { podzolised chemozem }\end{array}$ & $5.4-6.5$ & $1.0-3.0$ & $18.2-27.4$ & $37.68-41.15$ \\
\hline Clay & $\begin{array}{l}\text { Heavy } \\
\text { loam, Clay }\end{array}$ & $\begin{array}{l}\text { Dark grey forest; leached cher- } \\
\text { nozem; podzolised chemozem; } \\
\text { typical chemozem; ordinary } \\
\text { chemozem }\end{array}$ & $5.3-6.7$ & $1.5-3.0$ & $25.6-41.1$ & $36.02-62.13$ \\
\hline
\end{tabular}




\section{Statistical processing of data}

To evaluate the calculated soil to cereals grain transfer factors, statistical methods appropriate to small sample sizes were used [2]. The following step-by-step procedures were applied:

- For each datasheet i.e. each combination of soil/cereals grain, outliner detection criteria were used to identify any outliner values, which were subsequently eliminated. Dixon criterion was used for small datasheets (less than 25 samples).

- Following rejection of outliners, the characteristics of the distribution were identified. For the estimation of distribution density parameters Mieses criterion, modified for small data sets, was used. This procedure is more powerful than the more popular Kolmogorov or Chi-squared tests when dealing with small sample numbers.

- Standard statistical methods were used for large data sets. In particular, as transfer factors are often found to follow a log-normal distribution, this was checked for each datasheet.

- Geometrical mean values and $95 \%$ confidence intervals of ${ }^{137} \mathrm{Cs}$ transfer factors were calculated for each crop/soil type combination.

In the most cases the applied approach of integrating data by the identified soil groups has provided low variability within the data samples subjected to further analysis. Clear-cut relationships between ${ }^{90} \mathrm{Sr}$ and ${ }^{137} \mathrm{Cs}$ accumulation in grain of different crops and identified soil groups were found.

The obtained data allowed us to derive rather stable ratios of geometric means for transfer factors for different soil groups which confirm the validity of data generalisation within the identified soil groups.

\section{CONCLUSIONS}

1. The relationship exists between TF and soil type, thereby allowing the use of TF as a criterion for soil classification.

2. For the TF-based soil classification it is necessary that databases be developed to provide a sufficient size of sampling.

4. It is expedient when establishing relations between TF and soil parameters to make use of methods for data grouping and integration (factor analysis and other statistical techniques). In the search for TF dependencies on soil parameters or soil factors, a nonlinearity of relations between these characteristics needs to be taken into account.

5. A factor analysis has identified three factors, each being responsible for the manifestation of different soil properties (content of clay, content of organic matter, soil acidity).

6. The key soil parameters which influence ${ }^{137} \mathrm{Cs}$ accumulation in crops is granulometric composition (content particles $<0.01 \mathrm{~mm}$ or content particles $<0.001 \mathrm{~mm}$ ). This can be used for soil radioecological classification.

\section{References}

[1] Vadyunina A.G., Korchagina Z.A. Methods for studying of soil physical properties. Moscow, Agropromizdat, $1986,416 \mathrm{p}$.

[2] Zaks A. Statistical estimation. M., Statistika, 1976, 598 p. 